\title{
Analisis Pelatihan Merajut Dalam Mengembangkan Potensi Entrepreneurship Mahasiswa Universitas PGRI Wiranegara Pasuruan
}

\author{
Nunuk Indarti ${ }^{*}$, Zulfa Aprilia Pratiwi ${ }^{2}$, Sugeng Pradikto ${ }^{3}$ \\ 1,2,3Pendidikan Ekonomi, Fakultas Pedagogi dan Psikologi Universitas PGRI Wiranegara Pasuruan \\ 1Email: nunukindarti53@gmail.com; ${ }^{2}$ Email: zulfaauliapratiwi910@gmail.com; \\ ${ }^{3}$ Email: sugengpradikto@gmail.com \\ "Corresponding Author
}

(Received: 15 Oktober 2020; Accepted: 15 Desember 2020; Published: 10 Januari 2021)

\begin{abstract}
Abstrack. This study aims to determine; 1) The efforts made by students in developing entrepreneurial potential; 2) The effect of knitting training on the entrepreneurial potential of UNIWARA Students; 3) The results achieved by students with knitting training. This research is a qualitative and data collection technique using interviews. Knitting training plays an important role for students, one of which is to develop skills and explore potential in depth. The results of this training make students enthusiastic about participating in knitting training, because the benefits of this activity can be implemented by creating a knitting product that makes a profit if the product can be sold successfully. The effect of knitting training to develop students' entrepreneurial potential, namely: 1) Increasing the potential for student creativity; 2) Being able to know the potential that exists within oneself; 3) The results of knitting training can be implemented in the community; 4) Creating a work of knitting results; 5) Generate a profit side for works that are successfully sold; 6) Changing the mind set about job opportunities. Based on the results of the research, the researcher gave several recommendations as follows: 1) For students, it is hoped that they will continue to seek experiences at a young age with all the things that can be used. develop creativity. 2) For the next researcher it is suggested to look at other factors that influence entrepreneurial interest such as personality or environment. Alternatively, analyze the factors of interest in knitting training.
\end{abstract}

\section{Keywords: Knitting Training; Potential Entrepreneurship}

Abstrak. Penelitian ini bertujuan untuk mengetahui; 1) Upaya yang dilakukan mahasiswa dalam mengembangkan potensi entrepreneurship; 2) Pengaruh pelatihan rajut terhadap potensi entrepreneurship Mahasiswa UNIWARA; 3) Hasil yang dicapai mahasiswa dengan adanya pelatihan rajut. Penelitian ini bersifat kualitatif dan teknik pengumpulan data menggunakan wawancara. Pelatihan rajut sangat berperan penting bagi mahasiswa, salah satunya untuk menumbuh kembangkan skill dan menggali potensi secara mendalam. Hasil pelatihan ini menjadikan mahasiswa antusias untuk ikut berpartisipasi dalam pelatihan rajut, karena manfaat kegiatan ini bisa diimplementasikan dengan menciptakan suatu produk rajut yang menghasilkan profit jika produk bisa berhasil dijual. Pengaruh adanya pelatihan rajut untuk menumbuh kembangkan potensi Entrepreneurship mahasiswa yaitu: 1) Menambah potensi kreatifitas mahasiswa; 2) Dapat mengetahui potensi yang ada dalam diri sendiri; 3) Hasil dari pelatihan rajut dapat diimplementasikan ke masyarakat; 4) Menciptakan suatu karya hasil merajut; 5) Mendatangkan sisi profit untuk hasil karya yang berhasil dijual; 6) Merubah mind set nya tentang peluang kerja. Berdasarkan hasil penelitian peneliti memberikan beberapa rekomendasi sebagai berikut: 1) Bagi Mahasiswa di harapkan terus mencari pengalaman di usia muda dengan semua hal yang dapat mengembangkan kreativitas. 2) Bagi Peneliti selanjutnya disarankan agar mencermati faktor-faktor lain yang berpengaruh terhadap minat entrepreneurship seperti kepribadian, atau lingkungan. Bisa juga, analisis faktor minat dalam pelatihan rajut

Kata kunci : Pelatihan Merajut; Potensi Entrepreneurship 


\section{PENDAHULUAN}

Secara umum kultur masyarakat Indonesia masih banyak yang memilih profesi yang relatif "tanpa resiko" (misalnya saja menjadi pegawai negeri sipil atau bekerja di perusahaan besar). Pernyataan ini baru sebatas hipotesis dan fenomena yang harus dibuktikan kebenarannya. Namun, dengan kondisi persaingan usaha di era 4.0 ini, profesi yang relatif tanpa resiko sangat banyak pesaingnya dan kemungkinan besar juga akan bersaing dengan tenaga asing yang kualitas sumber dayanya sangat bagus. Tentu sangat tidak diharapkan apabila musuh pesaing kita adalah tenaga asing yang lebih banyak berkuasa di negara Indonesia. Maka dari itu perlunya suatu antusias yang sangat tinggi untuk memunculkan inovasi baru atau mengasa potensi diri dan memulai sebuah bisnis dibidang wirausaha.

Berawal dari pelatihan rajut tahun 2016 yang diadakan di Koperasi Mahasiswa Universitas PGRI Wiranegara Pasuruan ini sangat mengundang antusias mahasiswa untuk mengikuti pelatihan tersebut. ditambah lagi ada dukungan dari Dinas Pemuda dan Olahraga Kabupaten Pasuruan yang pada tanggal 25 Juni 2020 DISPORA Kabupaten Pasuruan mengadakan pelatihan rajut di Hotel Tanjung Plaza Tretes yang di selenggarakan selama 3 hari. Dari sana banyak mahasiswa dari UNIWARA yang mengikuti pelatihan rajut tersebut. sehingga ini menambah semangat untuk terus merealisasikan hasil dari ikut pelatihan rajut tersebut.

Awalnya hanya ada beberapa mahasiswa yang mengadakan pelatihan rajut seminggu sekali dan mengundang kakak tingkat sebagai coach, beliau yang sangat ahli dibidang merajut bahkan karyanya sangat banyak dan bernilai jual tinggi. Seiring berjalannya waktu, satu persatu mahasiswa mulai banyak yang mengikuti pelatihan ini, karena termotivasi dengan temantemannya yang membuahkan hasil. Sampai saat ini karya mahasiswa UNIWARA banyak yang terjual dan mereka semakin mempunyai potensi dalam berkarya maupun dalam berwirausaha. Karyanya semakin banyak dan mengikuti trend masa kini.

Dengan demikian banyak keuntungan dari mata kuliah kewirausahaan untuk mengembangkan potensi diri mahasiswa untuk berwirausaha, tidak hanya itu mata kuliah kewirausahaan yang diperoleh oleh pendidikan ekonomi berdampak kepada prodi lain terutama mahasiswa program studi matematika. Dengan itu meskipun berbeda program studi bisa bertukar pendapat dan dapat berkolaborasi untuk mengasa potensi dalam mengembangkan rajut di Universitas PGRI Wiranegara. Dengan cara mengadakan pelatihan dikampus untuk mengundang mahasiswa lain agar berantusias untuk berkarya.

Hanya sekedar membutuhkan modal benang, jarum rajut serta keterampilan yang mewadahi sudah mempunyai produk yang sangat bernilai dan juga akan mendapatkan penghasilan tambahan. Para mahasiswa ini biasanya mempromosikan hasil karyanya dengan menggunakan media sosial maupun mengikuti pameran-pameran di kota Pasuruan. Dengan adanya pelatihan ini dapat membangun nilai ekonomi kreatif sehingga sangat berpengaruh kepada mahasiswa yang nantinya akan membangun industri menuju Indonesia yang sejahtera. Sebagai upaya membuka kesempatan kerja, maka pelatihan kewirausahaan merupakan salah satu langkah terpenting bagi seseorang agar mampu untuk berwirausaha pada masa kini dan masa mendatang (Inanna et al., 2019). Mahasiswa tidak hanya mengejar nilai akademik di kampus melainkan mereka juga harus bisa menggali potensi yang mereka miliki dengan cara mengikuti beberapa organisasi yang bisa membuat mahasiswa dikenal perannya sebagai agent of change yang menjadi inisiator pergantian sebuah era. Akan tetapi juga harus pandai memanage waktu dalam proses akademik dan organisasinya.

Suasana akademik untuk menciptakan semangat kewirausahaan ini harus dilakukan sejak mahasiswa mulai menapaki kehidupannya dalam kampus (sebagai mahasiswa baru) dan terus berkelanjutan sampai mereka lulus menjadi sarjana. Keterpaduan kemampuan dalam mengakses ilmu dan pengetahuan hard skills dan kemampuan pencapaian tata nilai kehidupan soft skills merupakan metode yang efektif dalam menumbuhkan semangat dan budaya kewirausahaan dengan kecakapan hidup (Dougia, 2020). Oleh sebab itu, masalah kewirausahaan sangat menarik bukan hanya pada tataran kajian konseptual, melainkan pula pada aspek aplikasi. Sebab, kewirausahaan (entrepreneurship) ternyata tidak cukup hanya mengkaji teori atau konsep-konsep teoretis (Kuratko, 2016).

Berawal dari pelatihan rajut tahun 2016 yang diadakan di Koperasi Mahasiswa Universitas PGRI Wiranegara Pasuruan ini sangat mengundang antusias mahasiswa untuk mengikuti pelatihan tersebut. ditambah lagi ada 
dukungan dari Dinas Pemuda dan Olahraga Kabupaten Pasuruan yang pada tanggal 25 Juni 2020 DISPORA Kabupaten Pasuruan mengadakan pelatihan rajut di Hotel Tanjung Plaza Tretes yang di selenggarakan selama 3 hari. Dari sana banyak mahasiswa dari UNIWARA yang mengikuti pelatihan rajut tersebut. sehingga ini menambah semangat untuk terus merealisasikan hasil dari ikut pelatihan rajut tersebut.

Awalnya hanya ada beberapa mahasiswa yang mengadakan pelatihan rajut seminggu sekali dan mengundang kakak tingkat sebagai coach, beliau yang sangat ahli dibidang merajut bahkan karyanya sangat banyak dan bernilai jual tinggi. Sampai saat ini karya mahasiswa UNIWARA banyak yang terjual dan mereka semakin mempunyai potensi dalam berkarya maupun dalam berwirausaha. Karyanya semakin banyak dan mengikuti trend masa kini.

Hanya sekedar membutuhkan modal benang, jarum rajut serta keterampilan yang mewadahi sudah mempunyai produk yang sangat bernilai dan juga akan mendapatkan penghasilan tambahan. Para mahasiswa ini biasanya mempromosikan hasil karyanya dengan menggunakan media sosial maupun mengikuti pameran-pameran di kota Pasuruan. Dengan adanya pelatihan ini dapat membangun nilai ekonomi kreatif sehingga sangat berpengaruh kepada mahasiswa yang nantinya akan membangun industri menuju Indonesia yang sejahtera. Mahasiswa tidak hanya mengejar nilai akademik di kampus melainkan mereka juga harus bisa menggali potensi yang mereka miliki dengan cara mengikuti beberapa organisasi yang bisa membuat mahasiswa dikenal perannya sebagai agent of change yang menjadi inisiator pergantian sebuah era. Akan tetapi juga harus pandai memanage waktu dalam proses akademik dan organisasinya.

Ruang lingkup penelitian bertujuan untuk untuk mengetahui (1) Upaya yang dilakukan mahasiswa dalam mengembangkan potensi entrepreneurship (2) Pengaruh pelatihan rajut terhadap potensi entrepreneurship Mahasiswa UNIWARA (3)Hasil yang dicapai mahasiswa dengan adanya pelatihan rajut.

\section{METODE PENELITIAN}

Metode penelitian ini dilakukan dengan menggunakan pendekatan studi kasus. Jenis penelitian deskriptif kualitatif yang digunakan pada penelitian ini dimaksudkan untuk memperoleh informasi mengenai pelatihan merajut dalam mengembangkan potensi entrepreneurship mahasiswa Universitas PGRI Wiranegara Pasuruan secara mendalam dan komprehensif. Selain itu, dengan pendekatan kualitatif diharapkan dapat diungkapkan situasi dan permasalahan yang dihadapi dalam mengembangkan potensi entrepreneurship mahasiswa Universitas PGRI Wiranegara Pasuruan.

Penelitian ini menganalisis tentang pelatihan merajut apakah sudah dapat mengembangkan potensi entrepreneurship mahasiswa atau belum. Sesuai dengan pernyataan (Aminah, 2019) mengungkapkan bahwa penelitian kualitatif titik tekannya untuk memahami makna dari penelitian yang telah dibangun peneliti lain atau fenomena yang terjadi. Perlu diketahui bahwa penelitian kualitatif adalah penelitian yang bermaksud untuk memahami fenomena tentang apa yang dialami oleh subjek penelitian misalnya perilaku, persepsi, motivasi, tindakan, dan lain-lain (Moleong, 2012).

\section{Subjek/Objek Penelitian}

Sukardi, (2006) berpendapat bahwa subyek penelitian sama dengan key informan yaitu orang yang mempunyai hubungan erat dengan suatu penelitian yang dapat memberikan informasi tentang informasi dan kondisi latar belakang. Untuk mendapat data yang tepat maka perlu ditentukan informan yang memiliki kompetensi dan sesuai dengan kebutuhan data (purposive). Adapun subjek dalam penelitian ini yaitu terdiri dari: (1) Mahasiswa Universitas PGRI Wiranegara, (2) Kepala Seksi Pengembangan Organisasi Pemuda Dinas (DISPORA) Pemuda dan Olahraga Kabupaten Pasuruan.

Objek penelitian ini dapat dinyatakan sebagai situasi sosial penelitian yang ingin diketahui apa saja yang terjadi didalamnya. Pada objek penelitian ini, peneliti dapat mengamati secara mendalam aktivitas (activity), orangorang (actors) yang ada pada tempat (place) tertentu (Sugiyono, 2011). Objek dalam penelitian ini yaitu pengembangan potensi entrepreneurship mahasiswa setelah diadakannya pelatihan merajut di Universitas PGRI Wiranegara Pasuruan.

Lokasi penelitian untuk memperoleh data dan informasi dari subjek penelitian berada Universitas PGRI Wiranegara Pasuruan

\section{Instrumen Penelitian}

Instrumen utama dalam penelitian kualitatif tidak lain adalah peneliti sendiri. Menurut 
(Sugiyono, 2017), dalam penelitian kualitatif instrumennya adalah orang atau human instrument, yaitu peneliti itu sendiri. Oleh karena itu, peneliti harus memiliki bekal teori dan wawasan yang luas sehingga mampu bertanya, menganalisis, memotret, dan mengkonstruksi situasi sosial yang diteliti menjadi lebih bermakna.

Dalam proses pengumpulan data dan informasi, peneliti menggunakan alat penunjang berupa:

- Buku catatan

- Smartphone (merekam gambar dan suara responden)

- Pedoman wawancara

Kehadiran peneliti dalam penelitian ini yaitu pengamat sebagai partisipan (nonpartisipan). Peneliti mengobservasi langsung kegiatan subjek yang diamati, namun tidak terlibat dalam kegiatan tersebut. Peneliti bertindak sebagai pengamat independen.

\section{Data dan Sumber Data}

Sebuah data tidak akan dapat diperoleh tanpa sumber data. Betapapun menariknya permasalahan suatu topik penelitian, bila sumber data tidak tersedia, penelitian tersebut tidak memiliki arti, sebab tidak bisa diteliti untuk dipahami (Nugrahani \& Hum, 2014).

Sumber data adalah subjek dari mana saja dapat diperoleh (Arikunto, 2010). Sumber data dalam penelitian ini adalah Mahasiswa Universitas PGRI Wiranegara, Kepala Seksi Pengembangan Organisasi Pemuda Dinas (DISPORA) Pemuda dan Olahraga Kabupaten Pasuruan serta data-data yang dapat diperoleh dan digali. Secara garis besar ada tiga jenis sumber data yang biasa disingkat dengan 3P (person, paper, place).

Teknik pengumpulan data berdasarkan sumber datanya dapat menggunakan sumber data primer dan sekunder. Sumber data primer yaitu memperoleh data dengan cara informan memberikan langsung data kepada pengumpul data. Sedangkan sumber data sekunder merupakan sumber yang tidak langsung memberikan data kepada pengumpul data, misalnya melalui orang lain atau dokumen.

Data primer dan data sekunder diperoleh melalui teknik pengumpulan data berdasarkan cara memperoleh data dari informan. Sugiyono, (2017) menuliskan bahwa teknik pengumpulan data dalam penelitian kualitatif umumnya digunakan pada observasi berperan serta (participant observation), wawancara mendalam (in depth interview), dan dokumentasi.
Dari pemaparan di atas maka, susunan teknik pengumpulan data dari penelitian ini yaitu:

- Data Primer

- Wawancara

Informan kunci dalam penelitian ini yaitu Mahasiswa Universitas PGRI Wiranegara dan Kepala Seksi Pengembangan Organisasi Pemuda Dinas (DISPORA) Pemuda dan Olahraga Kabupaten Pasuruan.

○ Observasi

- Data Sekunder

- Studi kepustakaan

Upaya peneliti dalam memperoleh data dan informasi tambahan melalui media jurnal, buku, koran/portal berita online, dan dokumen

Sehubungan dengan susunan teknik pengumpulan di atas, maka peneliti menggunakan teknik purposive sampling dalam memperoleh data primer. Sugiyono, (2017)) menuliskan bahwa teknik purposive sampling adalah teknik pengambilan sampel sumber data dengan pertimbangan sumber data dapat menjelaskan informasi yang peneliti harapkan sesuai dengan tujuan penelitian.

Teknik ini termasuk dalam kelompok nonprobability sampling yaitu teknik pengambilan sampel yang tidak memberi peluang sama bagi tiap anggota populasinya untuk dipilih menjadi sampel. Jenis teknik penelitian ini dipilih karena peneliti bisa lebih efektif dalam memperoleh informasi dan data yang akurat dari informan kunci serta lebih efisien dalam manajemen waktu dalam proses pengumpulan data.

\section{Prosedur Pengumpulan Data}

Pengumpulan data dalam penelitian ini yaitu dengan teknik observasi terus terang dan tersamar, wawancara mendalam (in depth interview) dan dokumentasi.

a) Observasi (terus-terang dan tersamar)

b) Wawancara mendalam

c) Dokumentasi

Dalam penelitian ini, peneliti melakukan pengumpulan data dengan triangulasi teknik. Triangulasi teknik dapat diartikan bahwa peneliti menggunakan teknik pengumpulan data yang berbeda-beda untuk memperoleh data yang sama secara serempak (Sugiyono, 2017).

Triangulasi dipilih karena peneliti mengumpulkan data sekaligus menguji kredibilitas data dengan berbagai teknik 
pengumpulan data sehingga data yang diperoleh lebih akurat.

\section{Analisis Data}

Dalam penelitian kualitatif ini, peneliti menggunakan teknik analisis data model Miles \& Huberman, (1984). Miles dan Huberman dalam Sugiyono, (2017) mengemukakan bahwa "Aktivitas dalam analisis data kualitatif dilakukan secara interaktif dan terus menerus sampai tuntas, sehingga datanya sudah jenuh". Dalam artian kualitatif tidak mengenal adanya jumlah sample minimum.

Data yang diperoleh, dianalisis dan dikemas secara runtut, padat, jelas, dan singkat serta tidak menimbulkan pertanyaan atau spekulasi baru yang terkesan belum tuntas. Adapun langkah-langkah aktivitas dalam analisis data yaitu:

\section{Pengumpulan Data (Data Collection)}

Pengumpulan data dilakukan dengan observasi, wawancara mendalam, dan dokumentasi atau gabungan ketiganya (triangulasi). Pada tahap awal, peneliti menggali berbagai informasi yang berhubungan dengan pengembangan potensi mahasiswa saat sebelum dan sesudah mengikuti pealatihan rajut, dengan begitu peneliti akan memperoleh data yang beragam dan bervariasi baik dari mahasiswa program studi lainnya.

\section{Reduksi Data (Data Reduction)}

Data yang beragam dan bervariasi selanjutnya direduksi. Kata reduksi secara harfiah berarti pengurangan atau pemotongan. Dalam penelitian, mereduksi data kerap diartikan dengan merangkum, memilih hal-hal pokok, fokus pada hal-hal yang dianggap penting, mencari tema dan pola data.

Mereduksi data memudahkan peneliti dalam mengidentifikasi data yang diperoleh sesuai dengan objek dan tujuan penelitian.

\section{Penyajian Data (Data Display)}

Setelah data inti terkumpul dan teridentifikasi, selanjutnya masuk pada tahapan penyajian data. Dalam penelitian kualitatif, data dapat disajikan berupa teks naratif singkat, bagan, grafik, network (jejaring kerja), dan chart. Penyajian data dibuat sepadat dan semenarik mungkin agar data yang disajikan lebih mudah dipahami oleh pembaca.

\section{Penarikan Kesimpulan dan Verifikasi} (Conclusion: Drawing/Verification)

Langkah terakhir dalam anlisis data kualitatif adalah penarikan kesimpulan dan verifikasi. Kesimpulan dalam penelitian kualitatif merupakan temuan baru, dapat berupa deskripsi atau gambaran suatu obyek yang sebelumnya belum pernah ada atau masih diragukan keberadaannya. Sehingga diperlukan verifikasi di lapangan.

Kesimpulan diambil berdasarkan keadaan di lapangan. Penelitian yang konsisten dengan mengumpulkan bukti-bukti yang valid akan menghasilkan kesimpulan yang kredibel.

\section{HASIL DAN PEMBAHASAN}

Pembahasan ini menyangkut Analisis Pelatihan Merajut Dalam Mengembangkan Potensi Entrepreneurship Mahasiswa Universitas PGRI Wiranegara Pasuruan

Temuan Penelitian

\section{Keberadaan Pelatihan Rajut di Kampus UNIWARA}

Dari hasil wawancara dengan Afif selaku Ketua Umum Koperasi Mahasiswa UNIWARA dari program Pendidikan Ekonomi angkatan 2017 yang menjadi Informan Kunci 1 (IK 1), Pelatihan ini untuk menumbuhkembangkan bakat mahasiswa, melatih kekreatifan, dan menambah skill. berikut pernyataan dari Afif Ma'aruf (IK 2):

"(10 Juli 2020)" Afif Ma'aruf mengatakan banyak antusias dari mahasiswa untuk mengikuti pelatihan rajut ini. KOPMA sendiri adalah salah satu wadah untuk mengasah atau mempelajari ilmu tentang entrepreneurship. Bagi mahasiswa yang mempunyai waktu luang bisa dijadikan peluang besar dalam mengikuti pelatihan rajut. Bukan hanya bisa dalam merajut akan tetapi nantinya juga bisa diajarkan cara pemasarannya juga, jadi tidak hanya menambah skill namun juga mengembangkan jiwa entrepreneurship. Pelatihan rajut ini merupakan ilmu yang dapat digunakan didalam masyarakat untuk meningkatan ekonomi dan dapat menambah keterampilan seseorang.

Hasil wawancara dengan Khoiril Himaayah Azizah, mahasiswa dari Pendidikan Matematika angkatan 2017 sebagai Informan Kunci 2 (IK 2), Ide bagus, karena dapat mengasah kreatifitas mahasiswa juga sebagai mata pencaharian dari mahasiswa untuk mahasiswa. berikut pernyataan dari Khoiril Himaayah Azizah (IK 2): 
"(10 Juli 2020)" saya anak matematika akan tetapi saya juga tidak mau kalah dengan anak program pendidikan lainya, saya akan buktikan bahwa setelah mengikuti pelatihan rajut ini bukan hanya pelatihan rajutnya saja yang didapatkan akan tetapi proses dalam pemasarannya, banyak sekali sebenarnya yang bisa saya dapat, maka dari itu saya sangat bersyukur dengan adanya pelatihan rajut di UNIWARA ini dapat mengasah potensi Mahasiswa untuk berwirausaha.

Hasil wawancara dengan Septiani Dwi Sukmawati, mahasiswa dari pendidikan Pancasila dan Kewarganegaraan angkatan 2016 sebagai Informan Kunci 3 (IK 3), pelatihan rajut ini sangat bermanfaat sekali bagi mahasiswa yang benar-benar ingin menggali secara dalam ilmu dan potensinya. berikut pernyataan dari Septiani Dwi Sukmawati (IK 3):

"(12 Juli 2020)" bisa saya terima karena dapat membantu dalam meningkatkan skill dan dapat menciptakan suatu karya. Dari hasil pelatihan ini saya gali lagi potensi yang sudah saya miliki. Semakin banyak belajar untuk membuat motif-motif baru semakin banyak peminat dengan hasil karya saya. Alhamdulillah pendapatan dari hasil merajut ini dapat membantu membeli kebutuhan sehingga saya tidak pernah lagi meminta uang kepada orang tua.

$$
\text { Hasil wawancara dengan Jihadti }
$$

Renovani Puji Lestari mahasiswa dari Pendidikan Bahasa Inggris angkatan 2016 sebagai Informan Kunci 4 (IK 4), bagus sekali ya, karena jarang banget orang yang mau terjun untuk mengkreasi dirinya sendiri sekreatif mungkin dan juga minim sekali adapun dia juga malas. berikut pernyataan dari Jihadti Renovani Puji Lestari (IK 4):

"14 Juli 2020" Saya sangat mendukung ketika ada pelatihan rajut dan juga saya sangat mengapresiasi karena itu kita bisa mengelolah hasil tangan kita sendiri untuk berkembang. Dan nantinya kita juga bisa menyalurkan bakat kita kepada masyarakat.

Hasil wawancara dengan Kepala Seksi Pengembangan Organisasi Pemuda DISPORA Kabupaten Pasuruan Sri Wahyuni, S.Pd sebagai informan Kunci 5 (IK 5), Pada dasarnya tidak semua mahasiswa tertarik yaa untuk mengikuti pelatihan rajut, akan tetapi nantinya bagaimana cara kita bisa memberikan suatu hasil yang sangat bernilai jual tinggi sehingga mahasiswa mengetahui nyata hasil pelatihan rajut ini. berikut pernyataan dari Sri Wahyuni S.Pd (IK 5):
"17 Juli 2020" kalau untuk membangun entrepreneur sih sangat bagus juga ya. Karena kalau dikampus hanya mengikuti perkuliahan begitu kuliah selesai tidak tau mau kemana, tapi kalau disitu ada pelatihan rajut minimal sambil menunggu pekerjaan yang tepat mahasiswa masih bisa beraktifitas mengikuti pelatihan rajut syukur itu bisa dikembangkan lagi.

\section{Pengaruh Pelatihan Rajut terhadap Potensi Entrepreneurship Mahasiswa}

Dari hasil wawancara dengan Afif selaku Ketua Umum Koperasi Mahasiswa UNIWARA dari program Pendidikan Ekonomi angkatan 2017 yang menjadi Informan Kunci 1 (IK 1), Sangat berpengaruh terhadap mahasiswa yang berminat mengikuti pelatihan ini, salah satunya menambah potensi kreatifitas mahasiswa. guna meningkatkan potensi mahasiswa maka saya berinisiatif terus melanjutkan dan memberikan pelatihan kreatifitas seni yang berupa pelatihan rajut. berikut pernyataan dari Afif Ma'aruf (IK 2):

"(10 Juli 2020)" sampai saat ini pelatihan rajut sangat berperan bagi mahasiswa UNIWARA. Awalnya hanya sedikit yang mengikuti dan sampai sekarang alhamdulillah semakin banyak yang berantusias untuk ikut pelatihan rajut.

Hasil wawancara dengan Khoiril Himaayah Azizah, mahasiswa dari Pendidikan matematika angkatan 2017 sebagai Informan Kunci 2 (IK 2), ini merupakan pengaruh yang sangat signifikan karena terkadang kita sebagai mahasiswa masih belum tau potensi yang ada dalam diri sendiri. Awalnya pelatihan ini dimulai dengan memahami konsep dasar merajut kemudian cara pemasarannya juga. berikut pernyataan dari Khoiril Himaayah Azizah (IK 2):

"(10 Juli 2020)" Jadi dengan adanya pelatihan rajut kita akan lebih mengetahui apa yang ada didalam diri kita, misal potensi dalam hal merajut yang awalanya tidak bisa menjadi bisa. Pelatihan ini sangat bermanfaat sekali untuk setiap mahasiswa yang beda fakultas, dimana mereka bisa berkolaborasi atau bisa saling tukar pendapat untuk berwirausaha. Dari pelatihan inilah secara tidak langsung kita di didik untuk membuat suatu karya yang bisa diperjual belikan.

Hasil wawancara dengan Septiani Dwi Sukmawati, mahasiswa dari Pendidikan Pancasila dan Kewarganegaraan angkatan 2016 sebagai Informan Kunci 3 (IK 3), pelatihan rajut ini sangat berpengaruh besar terhadap 
pengembangan potensi mahasiswa karena hasil dari pelatihan rajut dapat diimplementasikan, dengan menciptakan suatu karya hasil merajut juga bisa mendatangkan sisi profit untuk hasil karya yang berhasil dijual. Kepuasan yang dimiliki pun bukan cuma saat merajut karya yang cantik, unik, dan spesial, namun kepuasan batin saat orang lain menghargai karya kita atau mereka memakainya adalah perasaan yang tak ternilai. berikut pernyataan dari Septiani Dwi Sukmawati (IK3):

"(12 Juli 2020)" Saya sendiri memanfaatkan hasil yang saya peroleh selama mengikuti pelatihan. Alhamdulillah dengan skill saat ini yang saya punya bisa menambah pemasukan. Kegiatan merajut ini juga dapat menghubungkan orang-orang dengan hobi yang sama untuk saling bertukar pikiran, saling berbagi pola, dan saling mengajari satu sama lain.

Hasil wawancara dengan Jihadti Renovani Puji Lestari mahasiswa dari Pendidikan Bahasa Inggris angkatan 2016 sebagai Informan Kunci 4 (IK 4), merajut merupakan aktivitas tangan yang mengolah sehelai benang rajut menggunakan jarum rajut. Dari adanya pelatihan rajut ini sangat berpengaruh terhadap potensi entrepreneurship. berikut pernyataan dari Jihadti Renovani Puji Lestari (IK 4):

"14 Juli 2020" semisal gini kita punya hasil karya kenapa tidak mencoba untuk menjualnya dan dapat menghasilkan uang. Meskipun tidak semua orang bisa mendapatkan banyak uang dari merajut, namun setidaknya ada aspek positif yang dirasakan seseorang mampu menjual hasil karya rajutannya.

Hasil wawancara dengan Kepala Seksi Pengembangan Organisasi Pemuda DISPORA Kabupaten Pasuruan Sri Wahyuni, S.Pd sebagai informan Kunci 5 (IK 5), pelatihan rajut ini tidak cukup hanya diberikan begitu saja. Namun, evaluasi juga dibutuhkan. Hal ini agar pelatihan tidak hanya berhenti begitu saja. Harus ada dampak besar bagi para mahasiswa salah satunya memiliki jiwa entrepreneurship. berikut pernyataan dari Sri Wahyuni S.Pd (IK5):

"(17 Juli 2020)" mahasiswa dengan jiwa mudanya sangat potensial untuk mengasah skill dalam berwirausaha. Pelatihan rajut yang ada dikampus ini menunjukkan kepedulian mahasiswa untuk menumbuhkembangkan potensi tersembunyi yang ada pada diri mahasiswa. hal ini menunjukkan perhatian mahasiswa untuk merubah mind set nya tentang peluang kerja. Pengaruhnya mahasiswa mungkin perlahan akan mulai menyadari kalau ternyata dengan berwirausaha akan berdampak baik bagi dirinya terlebih lagi bangsa Indonesia. Dengan berwirausaha, akan banyak pengangguran yang terserap menjadi produktif. Pada akhirnya akan mengangkat perekonomian bangsa.

\section{Upaya Menumbuh kembangkan Potensi Entrepreneurship Mahasiswa}

Dari hasil wawancara dengan Afif selaku Ketua Umum Koperasi Mahasiswa UNIWARA dari Pendidikan Ekonomi angkatan 2017 yang menjadi Informan Kunci 1 (IK 1), potensi entrepreneurship ini adalah salah satu upaya untuk menjadikan mahasiswa bisa berwirausaha. Salah satu pemanfaatan potensi adalah dengan mengembangkan kewirausahaan muda. berikut pernyataan dari Afif Ma'aruf (IK 2):

"(10 Juli 2020)" Afif Ma'aruf mengatakan Jiwa entrepreneurship bisa dibentuk dengan dorongan orang lain seperti mendapatkan motivasi serta dari kemauan diri sendiri tanpa paksaan. Pada tahun ini kita pelan-pelan harus memiliki banyak inovasi dan kreatifitas. Hal yang paling utama adalah jangan takut untuk belajar dan mencoba.

Hasil wawancara dengan Khoiril Himaayah Azizah, mahasiswa dari Pendidikan Matematika angkatan 2017 sebagai Informan Kunci 2 (IK2), semuanya dimulai dengan niat dan keyakinan pada diri sendiri tanpa adanya paksaan karena tidak semua orang menginginkan berwirausaha. Berikut pernyataan dari Khoiril Himaayah Azizah (IK 2):

"(10 Juli 2020)" Kebanyakan dari mahasiswa kerap dibayangi oleh kekhawatiran akan penuh resiko. Mereka masih menganggap bahwa berwirausaha adalah salah satu hal yang menakutkan, salah satu upaya untuk memulai usaha yaitu dengan niat dan yakin bahwa apa yang dilakukan bermanfaat dan dibutuhkan oleh banyak orang. Seorang yang sukses berwirausaha adalah mereka yang yakin dengan dirinya sendiri dan berani untuk menjadi berbeda melakukan apa yang terbaik untuk lingkungannya.

Hasil wawancara dengan Septiani Dwi Sukmawati, mahasiswa dari Pendidikan Pancasila dan Kewarganegaraan angkatan 2016 sebagai Informan Kunci 3 (IK 3), Mahasiswa tidak perlu takut mencoba dengan hal baru. Singkirkan rasa takut gagal saat mencoba hal baru yang belum kita pelajari. Kita hanya perlu waktu untuk menggali lebih dalam aktivitas dan keahlian baru. berikut pernyataan dari Septiani Dwi Sukmawati (IK3): 
"(12 Juli 2020)" Dengan mencoba hal baru juga bisa mendorong diri sendiri untuk keluar dari zona nyaman dan siapa tau nanti kita bisa menemukan bakat terembunyi dalam diri sendiri. Satu penghargaan yang tinggi dan mulia bagi seseorang yang pernah menempuh pendidikan tinggi.

Hasil wawancara dengan Jihadti Renovani Puji Lestari mahasiswa dari Pendidikan Bahasa Inggris angkatan 2016 sebagai Informan Kunci 4 (IK 4), setiap manusia dianugerahi potensi diri yang sangat luar biasa. Menariknya manusia sendiri sering tidak mengetahui dengan pasti potensi dirinya sendiri. berikut pernyataan dari Jihati Renovani Puji Lestari (IK4):

"(14 Juli 2020)" Itu semua tergantung individunya masing-masing terlebih dulu kita harus menumbuhkan dari diri kita sendiri, kalau kamu mau sukses dengan tanganmu sendiri ya berkarya. Karena kebanyakan mahasiswa menginginkan hal yang instan tanpa mau berusaha. Target agar usaha kita banyak peminat kita harus mencari pemasaran. Kita harus pandai dalam memasarkan produk.

Hasil wawancara dengan Kepala Seksi Pengembangan Organisasi Pemuda DISPORA Kabupaten Pasuruan Sri Wahyuni, S.Pd sebagai informan Kunci 5 (IK5), potensi yang dimiliki setiap manusia pastinya berbeda-beda. Meski untuk beberapa aspek ada juga yang memiliki kesamaan. Semua potensi tersebut tidak akan muncul dengan sempurna jika tidak dikembangkan dengan baik dan cara yang benar. berikut pernyataan dari Sri Wahyuni S.Pd (IK5):

"(17 Juli 2020)" selama ini saya hanya mencarikan jalan apabila mereka memang serius dibidang itu. saya sangat yakin bahwa pemuda di Kabupaten Pasuruan ini banyak yang memiliki potensi namun mereka masih belum mengenali potensinya dirinya sendiri, ketika saya langsung terjun kemasyarakat ternyata banyak sekali pemuda yang mempunyai potensi, nah sekarang ini tinggal bagaimana mengatur strategi agar potensi itu bisa dimanfaatkan. Peran dispora ini hanya pendampingan saja dan salah satu tempat untuk mengembangkan potensi pemuda. Akan tetapi tidak semua orang mengenal DISPORA, saya juga harus terjun langsung untuk memperkenalkan dan mencari potensi pemuda, begitu ketemu dan mereka mau langsung saya kasih arahan dan pendampingan. Yang terpenting nikmati saja setiap prosesnya karena dari terbentur maka kalian akan terbentuk.

\section{Analisi hasil temuan}

\section{Adanya Pelatihan Rajut di PGRI Wiranegara Pasuruan \\ Universitas}

Dari hasil penelitian yang dilakukan dengan wawancara kepada informan kunci bahwa pelatihan rajut sangat berperan penting bagi mahasiswa salah satu untuk menumbuhkembangkan skill dan menggali potensi secara mendalam. Dengan adanya pelatihan ini banyak antusias dari mahasiswa yang ikut berpartisipasi. pelatihan rajut ini bukan hanya pelatihan rajutnya saja yang didapatkan akan tetapi proses dalam pemasarannya juga, maka dari itu banyak mahasiswa yang sangat mengapresiasi adanya pelatihan rajut di UNIWARA. Selain itu juga dapat mengasah potensi Mahasiswa untuk berwirausaha.

Seperti yang dikemukakan oleh Rahayu, Rasid, \& Tannady, (2019), Pelatihan adalah suatu proses dimana orang-orang mencapai kemampuan tertentu untuk membantu mencapai tujuan organisasi. pelatihan dapat dipandang secara sempit maupun luas. Secara terbatas, pelatihan menyediakan para pegawai dengan pengetahuan yang spesifik dan dapat diketahui serta keterampilan yang digunakan dalam pekerjaan mereka saat ini. Terkadang ada batasan yang ditarik antara pelatihan dengan pengembangan, dengan pengembangan yang bersifat lebih luas dalam cakupan serta memfokuskan pada individu untuk mencapai kemampuan baru yang berguna baik bagi pekerjaannya saat ini maupun di masa mendatang (Afanasyev et al., 2019).

\section{Pengaruh Pelatihan Rajut terhadap Potensi Entrepreneurship Mahasiswa}

Dari hasil penelitian Pengaruh Pelatihan Rajut terhadap Potensi Entrepreneurship Mahasiswa, melakukan wawancara terhadap informan kunci bahwa "pelatihan rajut ini sangat memberikan nilai positif sehingga dapat menumbuhkembangkan skill mahasiswa untuk menjadi entrepreurship yang sukses karena hasil dari pelatihan rajut dapat diimplementasikan dengan menciptakan suatu karya hasil merajut juga bisa mendatangkan sisi profit untuk hasil karya yang berhasil dijual. Kepuasan yang dimiliki pun bukan cuma saat merajut karya yang cantik, unik, dan spesial. Namun kepuasan batin saat orang lain menghargai karya kita atau sat mereka memakainya adalah perasaan yang tak ternilai". Seperti yang dikemukakan oleh Sri Habasi dalam buku "Bimbingan dan Konseling kelas XI"adalah kemampuan dan kekuatan yang dimiliki oleh seseorang baik fisik maupun mental dan mempunyai kemungkinan untuk 
dikembangkan bila dilatih dan ditunjang dengan sarana yang baik.

\section{Upaya menumbuh kembangkan Potensi Entrepreneurship Mahasiswa}

Dari hasil penelitian Pengaruh Pelatihan Rajut terhadap Potensi Entrepreneurship Mahasiswa, melakukan wawancara terhadap informan kunci bahwa hasil dari penelitian ini telah menemukan beberapa upaya untuk Menumbuh kembangkan Potensi Entrepreneurship Mahasiswa. Adapun upayaupaya yang bisa digunakan antara lain:

1) Dimulai dengan niat dan keyakinan pada diri sendiri tanpa adanya paksaan

2) Menumbuhkan dari diri kita sendiri

3) Mahasiswa tidak perlu takut mencoba dengan hal baru

4) Jangan pernah takut gagal

5) Dikembangkan dengan baik dan cara yang benar

6) Mengatur strategi agar potensi itu bisa dimanfaatkan

7) Mengikuti pelatihan dan seminar entrepreneurship

Peneliti menjelaskan bahwa hasil temuan informan dari Kepala Seksi Pengembangan Organisasi Pemuda DISPORA Kabupaten Pasuruan juga berpengaruh terhadap menumbuhkembahkan potensi mahasiswa, salah satunya yakni pelatihan rajut. Dari sini dapat menguatkan argumen peneliti. Dari beberapa mahasiswa pernah ikut pelatihan rajut yang diselenggarakan oleh DISPORA di Hotel Tanjung Plaza Tretes. Sehingga tindak lanjut dari pelatihan tersebut diimplementasikan dikampus untuk mengajak mahasiswa lainnya berkarya.

Dari hasil penelitian ini dapat disimpulkan bahwa informan kunci sudah menjawab beberapa pertanyaan yang diajukan bahwa informan kunci memberikan suatu rancangan beberapa upaya yang diharapkan memberikan dampak positif untuk mencapai tujuan menumbuhkan potensi entrepreneurship pada diri mahasiswa Universitas PGRI Wiranegara (UNIWARA) Pasuruan.

\section{KESIMPULAN DAN SARAN}

Kesimpulan yang dapat diambil dari penelitian yang berjudul Analisis Pelatihan Merajut Dalam Mengembangkan Potensi Entrepreneurship Mahasiswa Universitas PGRI Wiranegara Pasuruan adalah:
1. Keberadaan Pelatihan Rajut di Kampus Universitas PGRI Wiranegara Pasuruan sangat memberikan nilai yang positif sehingga dapat membantu menumbuh kembangkan skill mahasiswa untuk menjadi seorang entrepreneur yang sukses.

2. Pelatihan rajut berpengaruh terhadap berkembangnya potensi mahasiswa bidang Entrepreneurship karena hasil dari pelatihan rajut dapat diimplementasikan dengan menciptakan suatu hasil karya yang berhasil dijual. Kepuasan yang dimiliki pun bukan Cuma saat merajut karya yang cantik, unik dan spesial namun kepuasan batin saat orang lain menghargai karya kita atau saat memakainya adalh perasaan yang tak ternilai. Potensi lain mahasiswa yaitu bakat memasarkan hasil rajut serta melihat peluang pasar.

3. Upaya menumbuh kembangkan potensi entrepreneurship mahasiswa, adapun upaya itu adalah dimulai dengan niat dan keyakinan pada diri sendiri tanpa adanya paksaan, menumbuhkan dari diri sendiri sehingga keyakinan itu menjadi modal utama yang kuat untuk berwirausaha yang sukses, mahasiswa tidak perlu takut mencoba dengan hal yang baru sehingga karya yang dihasilkan menjadi inovasi tersendiri bagi produknya, mengatur strategi dalam marketing serta inovasi produk sehingga potensi itu bisa dimanfaatkan untuk masa depannya menjadi entrepreneurship yang sukses diera digital 5.0

Berdasarkan hasil penelitian yang telah peneliti lakukan, serta kesimpulan yang ada, peneliti menyadari bahwa masih banyak kekurangan didalamnya. Sehingga peneliti memberikan beberapa rekomendasi yang kiranya dapat dijadikan sebagai bahan pertimbangan bagi pihak-pihak terkait, yakni sebagai berikut:

1. Keberadaan Pelatihan Rajut di Kampus Universitas PGRI Wiranegara Pasuruan sangat memberikan nilai yang positif di harapkan mahasiswa terus mencari pengalaman diusia muda dengan semua hal yang dapat mengembangkan kreativitas. Sehingga pada usia dewasa tengah, mereka sudah dapat mengembangkan karirnya menuju sukses tanpa khawatir dengan persaingan MEA. Serta meningkatkan pengetahuan terkait dunia usaha supaya usaha yang akan di jalankan semakin berkembang dan maju. 
2. Agar pelatihan rajut dapat berpengaruh terus terhadap berkembangnya potensi mahasiswa bidang Entrepreneurship maka, perlu mengadakan kerjasama dengan pemerintah kota khususnya Dinas perindustrian dan perdagangan kota Pasuruan untuk bersedia memfasilitasi pelatihan dan seminar tentang pengembangan produk rajut menjadi ciri khas bagi kota Pasuruan

3. Terus berupaya menumbuh kembangkan bakat entrepreneur mahasiswa dengan memberikan motivasi untuk mengembangkan produknya dengan strategi marketing mix dan membangun jaringan agar produknya dapat dikenal baik lokal maupun internasional.

\section{DAFTAR RUJUKAN}

Afanasyev, V. V., Ivanova, O. A., Rezakov, R. G., Afanasyev, I. V., \& Kunitsyna, S. M. (2019). Organizational environment for the schoolchildrens' professional identities: establishing, modelling, efficiency expectations and long-term development. International Journal of Civil Engineering and Technology, 10(2), 1612.

Aminah, S. (2019). Pengantar Metode Penelitian Kualitatif. Prenada Media.

Arikunto, S. (2010). Metode Peneltian. Jakarta: Rineka Cipta.

Dougia, E. (2020). Entrepreneurial skills development: A study of how Greek state Vocational Upper Secondary schools adopted an entrepreneurship strategy in order to grow soft skills in their students.

Inanna, I., Rahmatullah, R., \& Nurdiana, N. (2019). Pembelajaran kewirausahaan berbasis hand made. Seminar Nasional Lembaga Penelitian Dan Pengabdian Kepada Masyarakat Universitas Negeri Makassar, 173-176.

Kuratko, D. F. (2016). Entrepreneurship: Theory, process, and practice. Nelson Education.

Miles, M. B., \& Huberman, A. M. (1984). Qualitative data analysis: A sourcebook of new methods. In Qualitative data analysis: a sourcebook of new methods. Sage publications.

Moleong, L. J. (2012). Metodologi Penelitian Kualitatif, Edisi Revisi Cet. Ketigapuluh. Bandung: Remaja Rosdakarya Bandung.

Nugrahani, F., \& Hum, M. (2014). Metode Penelitian Kualitatif. Solo: Cakra Books. Rahayu, M., Rasid, F., \& Tannady, H. (2019). The Effect of Career Training and
Development on Job Satisfaction and its Implications for the Organizational Commitment of Regional Secretariat (SETDA) Employees of Jambi Provincial Government. International Review of Management and Marketing, 9(1), 79. Sugiyono. (2011). Metodologi penelitian kuantitatif kualitatif dan R\&D. Alpabeta, Bandung.

Sugiyono. (2017). Metode Penelitian Bisnis: Pendekatan Kuantitatif, Kualitatif, Kombinasi, dan R\&D. Penerbit $C V$. Alfabeta: Bandung.

Sukardi, M. S. (2006). Penelitian KualitatifNaturalistik Dalam Pendidikan. Yogyakarta: Usaha Keluarga. 